\title{
Mensagem do Presidente da ABPol
}

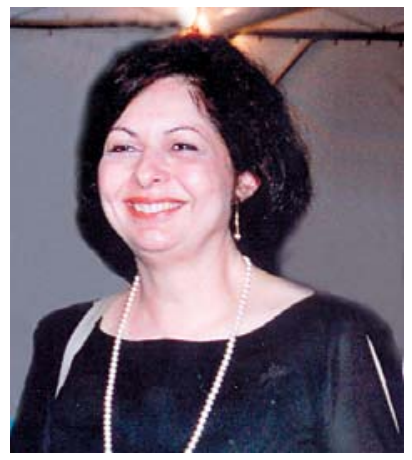

O Congresso Mundial de Polímeros, Macro 2006, em sua 41ª Edição, é uma realidade que está acontecendo na cidade do Rio de Janeiro. Este é o maior evento internacional da área de polímeros e é patrocinado pela International Union of Pure and Apllied Chemistry (IUPAC), abrangendo todas as áreas do conhecimento em polímeros. A realização deste Congresso em nosso país só foi possível graças à visão do Prof. Roberto F. S. Freitas de acreditar que o Brasil, através da ABPol, teria condições e seria capaz de realizar um evento desse porte e com o nível de responsabilidade exigido. As negociações se iniciaram há 8 anos e a competência e a disposição de realização do evento tiveram que ser reafirmadas a cada dois anos. Essas ações contaram também com a participação principalmente do Engenheiro Edson Simielli e dos Professores Sebastião Canevarolo, David Tabak e Ailton S. Gomes. A ABPol deve registrar um agradecimento a todos eles e a todas as outras pessoas que lutaram e contribuíram nesse processo.

Junto com o Macro 2006 está sendo realizado o X Simpósio Latino Americano de Polímeros (SLAP), que é um evento realizado também a cada dois anos em um país latinoamericano. A grande participação da comunidade nesses eventos tem fortalecido as interações pessoais e científicas de seus membros, contribuindo para a realização de projetos conjuntos e diversos intercâmbios, principalmente entre os jovens pesquisadores. A comunidade brasileira se sente honrada em receber nossos convidados da América Latina, Portugal e Espanha.

Raquel S. Mauler

\section{EDITORIAL}

This issue of Polimeros: Ciência \& Tecnologia is dedicated to the IUPAC/MACRO 2006 held in Rio de Janeiro from July 16 thru 21, 2006. After 32 years that important international meeting on polymers is held again in Brazil. Polimeros: Ciência \& Tecnologia is a journal edited by the Brazilian Polymer Society - ABPol and reaches all Latin America polymer community. The current issue was mostly edited in English language to allow all MACRO 2006 participants from abroad to know how is elaborated the most important Brazilian journal on Polymer Science \& Technology. There are two main sections, one, editorial section, is dedicated to cover general subjects about the Brazilian polymer community and another one, technical section, where scientific and technological articles are published. In the editorial section is shown a report about the IUPAC meeting call Polymer Symposium held in 1974 in Rio de Janeiro, where several outstanding Polymer scientists were present. Some of them made important contributions to the actual stage of the Polymer Science.

The on-line submissions program of Polimeros: Ciência \& Tecnologia has already been used by several authors and is working very well. The editorial committee is looking forward to have several papers submitted from the participants from the MACRO 2006, after the event. All papers may be submitted in Portuguese, English or Spanish.

The Polimeros: Ciência \& Tecnologia Editorial Committee has established a cooperative action with the Italian Macromolecule Science \& Technology Society (Associazione Italiana di Scienza e Tecnologia delle Macromolecole - AIM) to publish articles from the AIM Journal (Magazine), as was done in this issue. The same procedure has been already done by the AIM Magazine with an article from Polimeros: Ciência \& Tecnologia. It is an excellent opportunity to exchange knowledge and publishing experience. 